\title{
STRATEGI KOMUNIKASI DA'I DALAM MENANAMKAN NILAI-NILAI AGAMA BAGI ANAK-ANAK JALANAN DI PINANG BARIS KECAMATAN MEDAN SUNGGAL
}

\author{
Rholand Muary, Julina \\ rholandmuary@gmail.com
}

\section{Program Studi Sosiologi Agama Fakultas Ilmu Sosial UIN SU}

\begin{abstract}
ABSTRAK
Tujuan Penelitian adalah untuk mengetahui metode penelitian komunikasi Da'i dalam Menanamkan Nilai-Nilai Agama kepada Anak-anak Jalanan, hambatan dari komunikasi Da'i dalam Menanamkan Nilai-Nilai Agama kepada Anak-anak Jalanan di Pinang Baris Kecamatan Medan Sunggal. Penelitian ini menggunakan metode penelitian kualitatif dengan pendekatan fenomenologi. Teknik pengumpulan data dalam penelitian ini adalah observasi dan wawancara. Hasil yang diperoleh pada penelitian ini adalah Strategi komunikasi Da'i dalam menanamkan nilai-nilai agama kepada anak-anak jalanan di Pinang Baris Kecamatan Medan Sunggal terdapat beberapa bentuk. Pertama Da'i memberikan pengarahan sepenuhnya dan berupaya memberikan motivasi kepada mereka agar mau bersekolah. Kedua Da'i menunjukkan ketauladanan dalam kehidupan seharihari. Ketiga mengajarkan anak-anak jalanan melaksanakan shalat, membaca AlQur'an dengan memberikan pengarahan agar dapat diamalkan mereka dalam kehidupannya. Hambatan-hambatan yang didapatkan dalam menanamkan nilainilai agama kepada anak-anak jalanan yaitu sulit diatur (bandel), kurangnya pengawasan (kontrol) ketika mereka berada di jalanan dan faktor lingkungan yang tidak kondusif.
\end{abstract}

Kata Kunci: Komunikasi Da’I, Nilai-Nilai Agama

\section{ABSTRACT}

The aim of the study was to find out the communication method of Da'i in Infusing Religious Values to Street Children, obstacles from Da'i's communication in Instilling Religious Values with Street Children in Pinang Baris, Medan Sunggal District. This study uses qualitative research methods with a phenomenological approach. Data collection techniques in this study were observation and interviews. The results obtained in this study are Da'i's communication strategy in instilling religious values with street children in Pinang Baris, Medan Sunggal Subdistrict, there are several forms. First Da'i gave full direction and tried to motivate them to go to school. Both Da'i show obedience in everyday life. The third teaches street children to pray, read the Qur'an by giving instructions so that they can be practiced in their lives. Obstacles obtained in instilling religious values to street children are unruly (stubborn), lack of supervision (control) when they are on the streets and non-conducive environmental factors.

Keywords: Da'I Communication, Religious Values 


\section{PENDAHULUAN}

Srategi pada hakekatnya adalah perencanaan (Planning) dan Manajemen (manajement) untuk mencapai suatu tujuan. tetapi untuk mencapai suatu tujuan tersebut srategi tidak hanya berfungsi sebagai peta jalan yang hanya menunjukkan arah saja, melainkan harus menunjukkan bagaimana taktik operasinya. Demikian pula srategi komunikasi merupakan paduan dari perencanaan komunikasi dan menejemen untuk mencapai suatu tujuan, untuk mencapai tujuan tersebut srategi komunikasi harus dapat menunjukkan bagaimana operasionalnya secara taktis harus dilakukan, dalam arti kata bahwa pendekatan (approach) bisa berbeda. sewaktu-waktu tergantung dengan situasi dan kondisi. seperti halnya dalam srategi bidang apapun, srategi komunikasi harus didukung oleh teori, karena teori merupakan pengetahuan berdasarkan pengalaman yang sudah diuji kebenarannya (Effendy, 1981:84).

Tujuan dari komunikasi adalah mengharapkan adanya partisipasi dari komunikasi atau ide-ide atau pesan yang disampaikan tersebut oleh pihak komunikator sehingga dengan pesan-pesan yang disampaikan tersebut terjadilah perubahan sikap dan tingkah laku yang diharapkan (Tasmara, 1997:7). dalam melaksanakan dakwah perlu adanya perencanaan yang matang, memiliki srategi dan pola yang disesuaikan dengan objek dakwah. Da'i harus bisa mengetahui tentang keadaan anak-anak jalanan sebagai mad'u atau jamaahnya seperti kondisi psikologi anak.

Islam adalah agama yang universal, sebagai rahmatan lil'alamin yang tidak terbatas hanya mengatur hubungan antara manusia dengan Kholiknya saja, tetapi juga meletakkan peraturan-peraturan dasar dalam berbagai aspek kehidupan. salah satu upaya menanamkan dan membudayakan nilai-nilai ajaran Islam, diperlukan adanya aktifitas dakwah, baik secara individual maupun dikoordinir melalui organisasi dan atau lembaga dakwah serta oleh segenap umat islam.

Aktifitas dakwah akan lebih afektif dan efesien jika dilaksanakan dengan mempergunakan cara-cara atau metode yang tepat untuk mencapai hal tersebut Da'i mempunyai peranan yang sangat penting, sebagai juru dakwah Da'i selalu berhadapan langsung dengan masyarakat. dan tak terkecuali anak-anak jalanan. 
yang kian lama kian banyak dijalanan. Baik itu menjadi pengemis, pengamen, pemulung sampah/barang-barang bekas, bahkan menjadi anak pang yang suka berada dijalanan.

Daradjat (1990:27) menyatakan bahwa gama yang ditanamkan sejak kecil kepada anak-anak merupakan bagian dari unsur-unsur kepribadiannya, akan bertindak menjadi pengendali dalam menghadapi segala keinginan dan dorongandorongan yang timbul. karena keyakinan agama menjadi bagian dari kepribadian itu, akan mengatur sikap dan tingkah laku seseorang secara otomatis dari dalam. tanpa diperintah anak akan mengerjakan perintah Allah dan meninggalkan larangannya.

Para Da'i dalam hal mengkomunikasikan pembinaan nilai-nilai agama (seperti menyuruh anak jalanan melaksanakan shalat, melaksanakan ibadah puasa, membaca Al-Qur'an dan berperilaku akhlakul karimah) bagi anak-anak jalanan tersebut antara satu dengan yang lainnya. terdapat variasi. anak-anak tersebut masing-masing memiliki orang tua. diantaranya tidak sedikit orang tua yang memaksa anaknya untuk selalu menerima pendapat atau jalan pikiran mereka.sikap otoriter seperti justru akan menghancurkan harga diri anak dan membuatnya merasa bersalah. alur komunikasi antara orang tua dan anak menjadi tidak sejalan. nilai-nilai ajaran agama yang dijadikan orang tua sebagai pesan dakwah tidak dapat tersampaikan. untuk itu para Da'i ikut andil dalam masalah ini, dengan menyampaikan dakwah kepada anak jalanan.

Kasiran (1993:39) menyatakan bahwa komunikasi antara Da'i dengan anak-anak jalanan melalui tingkah laku dan perbuatan yang merupakan manivestasi dari pola hidup dan corak interaksi yang dikembangkan dari keluarga dan lingkungan. Jadi komunikasi ini melalui sikap dan perbuatan orang-orang disekelilingnya. dan bahwasannya orang yang pertama dan utama bertanggung jawab terhadap kelangsungan hidup dan pendidikan anak (termasuk cara mendidik shalat, dan membaca Al-Qur'an). adalah orang tua dan Da'i sebagai pengarah atau penyampai pesan dakwah dalam ajaran islam.

Hal ini menjadi tantangan bagi para Da'i untuk memberikan terapi pendidikan atau arahan sehingga mereka tetap menjalankan kehidupannya 
membantu orang tua dan tetap menjalankan ibadahnya kepada Allah. tetapi mereka apabila tidak mengindahkan ajaran agama seperti melaksanakan shalat.

Bardasarkan hasil survey awal dilokasi penelitian diketahui bahwa belum optimal peranan Da'i kepada anak-anak jalanan tersebut. Da'i sebagai tempat untuk dapat mengarahkan mad'unya, tidak terkecuali anak-anak jalanan. Da'i membutuhkan metode yang tepat agar mereka menjadi terdidik dengan memiliki semangat kembali untuk dapat bersekolah. Baik itu mencari pengetahuan umum dan agama supaya mereka dapat terarah, tidak putus sekolah, dan memiliki masa depan seperti anak-anak yang lain pada umumnya.

Masyarakat yang bermukim di Pinang Baris Kelurahan Lalang Kecamatan Medan Sunggal, memiliki rasa kebersamaan yang tinggi. Dengan saling berhubungan atau menghargai yang satu dengan yang lainnya. Tidak terkecuali anak-anak jalanan masyarakat tidak menganggap rendah anak-anak jalanan sehingga Da'ipun sebagai juru Da'wah, dapat menghubungkan anak-anak jalanan kemasyarakat.

Srategi komunikasi Da'i dengan anak jalanan dalam membina nilai-nilai agama anak jalanan sebagaimana dimaksudkan di atas diduga belum berlangsung secara baik, ini terlihat dari banyak anak-anak jalanan yang sering tidak mendengarkan apabila Da'i memberikan bimbingan agar anak jalanan tersebut mengerjakan shalat dan hormat kepada orang tua dan masyarakat. Masih terlihat anak (muslim) yang tidak mengerjakan shalat, baik secara pribadi maupun berjama'ah dimesjid dan tidak mau mengaji Alqur'an, ada juga yang suka mengutarakan perkataan-perkataan yang tabu.

Berbagai gambaran tentang kehidupan beragama anak jalanan di Pinang Baris kelurahan Lalang Kecamatan Medan Sunggal perlu dicermati dengan cara melakukan penelitian. Hal ini menjadi penting mengingat anak merupakan asset bangsa untuk mengisi pembangunan agama, nusa dan bangsa pada masa mendatang. Dan pentingnya para Da'i dalam menyampaikan dakwah (ajaranajaran Islam) kepada anak-anak agar tergugah pintu hati mereka masing-masing.

Menurut Dr.Atwar, dalam Aidil (2010:10) anak jalanan sebagian besar menggunakan minuman keras, dan obat-obatan terlarang sebagai media interaksinya. media tersebut semata-mata digunakan untuk aktifitas berkumpul 
mereka dengan kelompok. Pada prinsipnya anak jalanan harus ditarik kembali dari jalanan dengan mengedepankan pemenuhan kebutuhan dasar penguatan ekonomi keluarga, pendidikan berkelanjutan nilai-nilai social dan budaya yang mendukung, dan lingkungan yang positif terhadap kesejahteraan anak. Dengan pembinaan yang diberikan kepada mereka tentunya dengan berbagai pelatihan dan pemenuhan kebutuhan mereka terhadap nilai-nilai agama.

Berdasarkan uraian latar belakang di atas, maka peneliti tertarik untuk melakukan penelitian dengan judul Strategi Komunikasi Da'i Dalam Menanamkan Nilai-Nilai Agama Bagi Anak-Anak Jalanan Di Kecamatan Medan Sunggal. Penelitian ini memfokuskan pada beberapa aspek yaitu

1. Metode komunikasi Da'i dalam menanamkan nilai-nilai agama kepada anak-anak jalanan di Pinang Baris Kelurahan Lalang Kecamatan Medan Sunggal

2. Hambatan dari komunikasi Da'i dalam menanamkan nilai-nilai agama kepada anak-anak jalanan di Pinang Baris Kelurahan Lalang Kecamatan Medan Sunggal.

\section{KAJIAN PUSTAKA}

\section{A. Strategi Komunikasi}

Strategi komunikasi terdiri dari dua kata strategi dan komunikasi. Sebelum menjelaskan tentang pengertian strategi komunikasi, maka peneliti terlebih dahulu akan membahas tentang strategi dan komunikasi. Siagian (1985:21) berpendapat bahwa srategi adalah cara-cara yang sifatnya mendasar dan fundamental yang akan dan oleh suatu organisasi untuk mencapai tujuan dan berbagai sasaran dengan selalu memperhitungkan kendala lingkungannya yang pasti akan dihadapi”. Sedangkan menurut Effendy (1990:32) srategi pada hakekatnya adalah perencanaan (planning) dan (management) untuk mencapai suatu tujuan. Tetapi untuk mencapai tujuan tersebut, srategi tidak berfungsi sebagai peta jalan yang taktik operasionalnya.

Sedangkan komunikasi menurut Effendy (1989:270) adalah suatu proses, penyampaian pikiran atau perasaan oleh seseorang (komunikasi). komunikasi akan berhasil apabila pikiran yang disampaikan dengan menggunakan perasaan 
yang disadari, sebaliknya komunikasiakan gagal jika sewaktu menyampaikan pikiran, perasaan tidak terkontrol.

Astrid (1997:33-40) juga menjelaskan bahwa proses komunikasi terbagi dalam dua tahap yaitu proses komunikasi secara primer dan proses komunikasi secara skunder. Proses komunikasi secara primer adalah proses penyampaian fikiran dan perasaan seseorang kepada orang lain dengan menggunakan lambang atau simbol sebagai media Proses komunikasi secara sekunder adalah penyampaian pesan oleh seseorang kepada orang lain dengan menggunakan alat dan sarana sebagai media.

Dari pengertian-pengertian di atas maka dapat disimpulkan bahwa strategi komunikasi adalah cara yang digunakan dalam menyampaikan pikiran atau perasaan. Menurut Effendi (1981: 84) mengatakan srategi komunikasi merupakan panduan dari perencanaan komunikasi (commmunicatian planning) dan manajemen tujuan tersebut srategi komunikasi harus dapat menunjukkan bagaimana operasionalnya secara taktis harus dilakukan, dalam arti kata bahwa pendekatan (approach) bisa berbeda sewaktu-waktu tergantung dari situasi dan kondisi. Effendy (2004:32) juga menjelaskan bahawa komunikasi merupakan paduan perencanaan komunikasi (communication planning) dengan telah ditetapkan.

Sedangkan menurut Arifin (1984: 10) mengatakan sesungguhnya suatu srategi adalah keseluruhan keputusan kondisional tentang tindakan yang akan dijalankan, guna mencapai tujuan. Jadi merumuskan srategi komunikasi, berarti memperhitungkan kondisi dan situasi (ruang dan waktu) yang dihadapi dan yang mungkin dihadapi masa depan, guna mencapai ektifitas. Dengan srategi komunikasi ini, berarti dapat ditempuh beberapa cara memakai komunikasi secara sadar untuk menciptakan perubahan pada diri khalayak dengan mudah dan cepat.

\section{B. Komunikasi Da'I Dalam Menanamkan Nilai-Nilai Agama Bagi Anak}

Menurut Langgalung (1986:52) salah satu cara efektif untuk menanamkan nilai-nilai agama pada anak yaitu mengajarkan anak hidup dalam lingkungan yang relegius. Da'i memberi ketauladanan tentang perilaku religius tersebut. pada anakanak jalanan ditanamkan pengertian tentang konsep hak milik, tentang cara 
berteman yang baik, cara mencurahkan kasih sayang. sikap sopan, dan tolong menolong sesamanya.

Mengajarkan nilai-nilai agama terhadap anak-anak jalanan harus di waspadai. dalam keadaan anak-anak jalanan bertambah matang, jelaskanlah kepada mereka alasan-alasan mengapa dalam islam memegang dan menjalankan nilai-nilai agama dan terbukalah untuk berdiskusi. Banyak bentuk kegiatan keagamaan yang dapat mengarahkan dan membina nilai-nilai agama anak jalanan. pembinaan pendidikan agama yang dilaksanakan dimaksudkan untuk mengarahkan anak kepada taqarrub kepada Allah SWT. Sebagaimana disebutkan oleh Gazalba (1983:113) sebagai berikut:

1. Memperhambakan diri kepada Allah, yakni taat dan berserah diri kepada Allah.

2. Lembaga-lembaga agama untuk menjaga hubungan dengan Allah dan lembaga-lembaga sosial untuk menjaga hubungan dengan manusia sebagai lanjutan hubungan yang pertama.

3. Mewujudkan salam dunia dan akhirat

4. Tuntutan kepada amal saleh

5. Memberi pegangan kepada umat dalam mengamal agama dan sosial. lembaga mencapai tujuannya melalui norma-norma.

Di samping itu pembinaan dan pengarahan yang dilakukan terhadap remaja bukan hanya sekedar memenuhi pengetahuan agama terhadap ajaran islam, tetapi lebih dari itu diharapkan anak jalanan mampu mengamalkan (mengaplikasikannya) dan mengajarkaannya kembali kepada orang lain baik secara lisan maupun melalui perbuatan sehari-hari (contoh). dengan cara seperti inilah diyakini islam akan tetap hidup dan iman akan tetap kokoh.

\section{Anak Jalanan}

Ritzer dkk (2004:17) mengatakan anak jalanan digambarkan sebagai kelompok masyarakat dengan tingkat sratifikasi sosial rendah atau merupakan golongan bawah "grassroots" dengan status sosial serta posisi keuangan/wewenang (power/autority) yang tidak jelas. tidak memiliki banyak akses kesumber daya serta tidak memiliki kemampuan untuk menjadi subjek. 
Salah satu faktor banyaknya anak-anak jalanan adalah adanya masalah kemiskinan yang dialami oleh anak jalanan dan keluarganya. disisi lain juga adanya struktur sosial dalam masyarakat, yang menyebabkan terjadinya differensiasi sosial sebagai dampak adanya sratifikasi sosial dalam masyarakat.sratifikasi sosial diartikan Sajogyo (1985: 12) sebagai pembedaan penduduk atau masyarakat kedalam kelas-kelas secara bertingkat. manifestasi dari gejala sratifikasi sosial adalah adanya kelas-kelas tinggi dan kelas-kelas yang lebih rendah.

Dalam hal ini manakala terjadi perubahan dalam keluarga, misalnya ayah terkena pemutusan hubungan kerja, ibu terpaksa keluar rumah untuk membantu menopang ekonomi keluarga. manakala hasil yang diperoleh ibu tidak mencukupi kebutuhan anggota keluarga dan ayah belum memperoleh pekerjaan pengganti, maka anak menjadi asset untuk dapat menopang ekonomi keluarga dengan turun kejalanan.manakala anak sudah terlalu sering berada dijalanan dan nilai jalanan sudah terinternalisasi dalam diri anak jalanan, maka hubungan anak dengan orang tua menjadi kurang/tidak intensif. semakin terinternalisasinya nilai jalanan dalam diri anak jalanan, lingkungan disekitar anak jalanan relative dsemakin menganggap kehadiran anak jalanan sebagai troublemaker dan member "stigma" atau keberadaannya dijalanan.

Hal di atas terkait dengan pernyataan Soekanto (1991:20), manusia sebagai pengguna jalan raya memerlukan disiplin dan kebebasan. artinya manusia dapat menggunakan jalan raya dengan bebas. asal tidak menggaggu kebebasan orang lain sesama pennguna jalan raya. ketertiban dan disiplin menimbulkangannguan terhadap orang lain, sedangkan kehadiran anak dijalanan dengan berbagai aktifitasnya, sering kali dirasakan mengaggu sebagian orang.

\section{METODE PENELITIAN}

Penelitian ini berlokasi di Pinang Baris Kelurahan Lalang Kecamatan Medan Sunggal. tepatnya di PKPA (Pusat Kajian Perlindungan Anak) tempat dibinanya Anak-anak jalanan. Jenis penelitian ini adalah penelitian lapangan (field research) dengan metode kualitatif, yaitu prosedur penelitian yang menghasilkan data-data deskriptif berupa kata-kata dalam bentuk tulisan maupun lisan dari individu dann perilaku yang diamati. penelitian kualitatif berupa menggambarkan 
fenomena sosial secara holistic (utuh) tanpa perlakukan manipulatif. keaslian dan kepastian merupakan factor yang sangat ditekankan. Objek penelitian ini adalah anak-anak jalanan di sekitar Pinang Baris Kecamatan Sunggal. Sedangkan pendekatan yang digunakan dalam penelitian ini adalah pendekatan fenomenologis, yaitu metode penelitian yang memungkinkan penelitian untuk melakukan observasi, berinteraksi dan berusaha memahami tafsiran yang berkaitan dengan objek penelitiannya.

Informan kunci dalam penelitian ini yaitu 1 orang Da'i, yakni Iwan Hadi dan 1 orang Da'iah, yakni Wina Mariana Parinduri. yang ada di PKPA sebagai pembimbing, memberikan arahan dan binaan kepada anak-anak jalanan. Teknik pengumpulan data dalam penelitian ini adalah observasi, dan wawancara tidak berstruktur. wawancara tidak berstruktur merupakan wawancara yang bebas dan peneliti tidak menggunakan pedoman wawancara yang telah tersusun secara sistematis dan lengkap untuk pengumpulan datanya. Pedoman wawancara yang digunakan hanya berupa garis-garis besar prmasaalahan yang akan ditanyakan.

Kemudian teknik analisa data dalam penelitian ini dengan cara mereduksi data, menyajikan data dan menarik sebuah kesimpulan. Dalam penelitian kualitatif, analisis data dilakukan sejak awal penelitian dan selama proses penelitian dilaksanakan. data diperoleh, kemudian dikumpulkan untuk diolah secara sistematis. Dimulai dari observasi, wawancara, mengedit, mengklasifikasi, mereduksi, selanjutnya aktifitas penyajian data serta menyimpulkan data. Member check dilakukan dengan para informan, yaitu menanyakan kembali pernyataan yang telah terangkum dalam pemahaman peneliti, untuk memastikan kebenaran makna yang telah dibuat. Dengan cara demikian dapat dilakukan cross check sekaligus konfirmasi dalam menarik kesimpulan dari informasi yang telah direkam oleh peneliti. 


\section{HASIL PENELITIAN DAN PEMBAHASAN}

\section{A. Metode komunikasi Da'i Dalam Menanamkan Nilai-Nilai Agama Kepada Anak-Anak Jalanan Di Pinang Baris Kecamatan Medan Sunggal}

\section{Menyuruh Anak-Anak Jalanan Melaksanakan Ibadah}

Menyuruh anak melaksanakan ibadah dalam penelitian ini merupakan contoh komunikasi Da'i kepada anak-anak jalanan dalam bentuk komunikasi inter personal. Dalam bentuk komunikasi ini antara Da'i dengan anak-anak jalanan tidak hanya penyampaian pesan kepada anak, tetapi lebih dari itu Da'i menyampaikan fakta, ide yang bersifat mendidik dan mempengaruhi anak-anak jalanan untuk melaksanakan ibadah.

Sebagaimana hasil wawancara penulis dengan Bapak Irwan Hadi pada tanggal 28-4-2011 di rumah singgah PKPA di Pinang Baris Gg. Wakaf pada pukul 08.30 WIB, mengatakan:

Kalau sedang tidak masuk kerja dia selalu menyuruh anak-anak jalanan melaksanakan shalat berjama'ah di rumah, serta memantau anak-anak jalanan agar melakasanakan shalat dengan mempertanyakan pada waktu shalat "apakah kamu sudah melaksanakan shalat? seperti hasil wawancara dibawah ini, ustadz Irwan memberikan nasehat seperti berikut: "kamu harus melaksanakan shalat karena shalat itu adalah suatu kewajiban kita kepada Allah.

Wawancara dilakukan juga terhadap Da'i/Da'iah yang kedua yaitu Ibu Wina. Hasil wawancara pada tanggal 29 april 2011 pukul 09.30 WIB:

Menurut beliau yang bekerja sebagai Kepala Sekolah Anak Jalanan sekaligus sebagai ustadzah yang memberikan arahan kepada mereka. Menurutnya sekitar $+50 \%$ anak-anak jalanan yang menjalankan ibadah shalat dan membaca Al-Qur'an. Beliau juga mengatakan bahwa orang tua mereka yang turut bertanggung jawab memperhatikan pelaksanaan ibadah anak-anaknya sudah memberikan bimbingan dan nasehat, namun tetap saja anak-anak tersebut tidak mau mengerjakan ibadah. Dan untuk itu menurutnya butuh berbagai pelatihan dan pengarahan agar mereka memiliki kemauan dan pandai melaksanakannya. Tentunya mulai diajarkan sejak dini sampai tua nanti.

Beberapa responden yang peneliti wawancarai dalam kaitannya dengan strategi komunikasi yang dilakukan Da'i untuk menyuruh anak-anak jalanan melaksanakan ibadah, terdapat variasi yang dilatar belakangi pengalaman hidup 
masing-masing, latar belakang pendidikannya dan lingkungan keluarga yang harmonis. Artinya pengalaman para Da'i sangat berpengaruh positif terhadap anak-anak jalanan. Baik itu dari segi pendidikan dan peribadatan anak-anak jalanan. Di sisi lainnya semakin tinggi pengetahuan dan pendidikan, Da'i berkontribusi terhadap kemampuan membina dan mengarahkan anak-anak jalanan untuk melaksanakan ibadah shalat dan membaca Al-Qur'an.

Bagi Da'i secara langsung mengajari anak-anak jalanan belajar shalat dan membaca Al-Qur'an, hal ini termasuk teknik komunikasi informatif, karena Da'i tidak saja bertindak menyampaikan pesan-pesan tetapi lebih dari itu mengupayakan bagaimana caranya anak-anak jalanan sebagai lawan komunikasi bisa mengerti dan paham tentang apa yang disampaikan Da'i tersebut. Berdasarkan hasil wawancara dengan Ibu Wina pada tanggal 29 april 2011 pukul 09.30 WIB diketahui bahwa:

Pada umumnya anak-anak jalanan yang tidak bisa belajar shalat dan membaca Al-Qur'an mayoritas didominasi anak-anak jalanan yang orang tuanya berpenghasilan rendah (buruh kasar). Orang tua yang bekerja sebagai tukang becak, tukang bangunan, kuli angkat dan jenis pekerjaan kasar lainnya memiliki penghasilan rendah. Biaya untuk menyekolahkan anak dan membayar biaya anak-anak mereka untuk sekolah mengaji atau mendatangkan guru untuk mengajar anak-anak mereka dengan pendidikan agama sangat tidak memungkinkan.

Bapak Irwan pada tanggal 28 april 2011 pukul 08.30 WIB juga mengatakan orang tua anak jalanan yang pekerjaannya buruh kasar yang ada di Pinang Baris Kecamatan Medan Sunggal ini yang bisa mengajari anak-anak mereka belajar shalat dan membaca Al-Qur'an jumlahnya sedikit sekali.

Ibu Wina pada tanggal 29 april 2011 pukul 09.30 WIB menjelaskan lagi untuk mendidik anak-anak jalanan agar mau mengerjakan perintah Allah, selain dengan cara memberikan tauladan, teguran atau nasehat, juga dilakukan dengan cara menceritakan kisah-kisah orang yang jahat yang senantiasa dilaknat Allah SWT. Menurut Ibu Wina cara ini cukup efektif, selain memberikan pengetahuan kepada anak-anak jalanan juga berfungsi sebagai media anak untuk bisa menganalisa, membandingkan dan menimbang manfaat dan mudarat dari setiap perbuatan yang akan dilakukannya.

\section{Membimbing Anak-Anak Jalanan Melaksanakan Ibadah}

Para Da'i menunjukkan perhatian yang serius kepada anak-anak jalanan, hal ini terlihat dari paparan anak-anak jalanan ketika ditanyakan apakah Da'i 
kamu membimbing di tempat ini? jawabannya "ya", menurut ibu Wina pada wawancara tanggal 29 April 2011 di rumah singgah di Pinang Baris Gg. Wakaf pukul 09.30 WIB mengatakan:

Biasanya Da'i membimbing anak-anak jalanan pada waktu yang telah ditentukan sesuai dengan aturan yang ditetapkan agar mereka dapat aktif dan memiliki pengetahuan.

Selain Da'i berupaya menyuruh dan mengajarkan anak-anak jalanan melaksanakan ibadah shalat dan membaca Al-Qur'an, Da'i juga membimbing anak-anak jalanan untuk melaksanakan ibadah tersebut. Baik itu ibadah shalat dan membaca Al-Qur'an. Dengan adanya bimbingan yang dibuat oleh Da'i, anak-anak dapat lebih memahami atas pembelajaran yang telah diajarkan para Da'I sebelumnya kepada mereka. Dan anak-anak jalanan tersebut dapat mengamalkan ibadah shalat dan membaca Al-Qur'an didalam kehidupan mereka sehari-hari. Walau mereka sering berada di jalanan, namun para Da'i tidak henti-hentinya selalu memberikan arahan kepada mereka tujuannya agar terbukanya pemikiran mereka untuk menumbuhkan minat mereka bersekolah demi masa depan mereka masing-masing.

Hasil wawancara dengan Bapak Irwan Hadi pada tanggal 28 April 2011 pukul 08.30 WIB bahwa sifat komunikasi Da'i terhadap anak-anak jalanan dalam menanamkan kejujuran, ada tiga cara (sifat) yaitu komunikasi tatap muka, komunikasi verbal, dan komunikasi non verbal. Komunikasi tatap muka dengan cara menyampaikan secara langsung makna kejujuran, komunikasi verbal dengan cara menyampaikan secara langsung akan pentingnya kejujuran, dan komunikasi non verbal yang digunakan dengan isyarat atau gerak tubuh.

Strategi komunikasi Da'i terhadap anak-anak jalanan dalam menanamkan nilai-nilai agama salah satunya dengan perkataan yang baik. Hasil wawancara dengan Bapak Irwan pada tanggal 28 april 2011 pukul 08.30 WIB, Da'i yang melakukan komunikasi dalam bentuk informatif, terhadap anak-anak jalanan sebanyak 2 orang Da'i. Pola Da'i dalam menyampaikan perkataan yang baik terhadap anak-anak jalanan seperti ketika menyampaikan suatu informasi kepada anak-anak jalanan, Da'i menggunakan bahasa santun kepada mereka ketika mengajak, dan membujuk secara langsung serta mengarahkan anak-anak jalanan 
agar menggunakan perkataan yang baik, seperti membedakan cara bicara kepada orang tua dan teman sebaya. Berikut wawancara dengan Bapak Irwan:

Anak-anak ingatlah hidup kita hanya sementara. Marilah kita melaksanakan ibadah kepada Allah agar Allah selalu merahmati kita semua. Dan agar perbuatan-perbuatan kita senantiasa bersifat positif yang bermanfaat bagi diri kita juga bagi orang lain. Dan Da'i menggunakan teknik komunikasi hubungan kemanusiaan, seperti ketika anak-anak jalanan secara tidak sengaja berbicara perkataan yang kurang baik, Da'i tidak langsung memberikan hukuman kepada mereka tersebut melainkan Da'i hanya menasehati agar anak tidak mengulangi kesalahannya.

Di bawah ini hasil observasi peneliti yang peneliti rangkum tentang strategi komunikasi Da'I dalam menanamkan nilai-nilai agama kepada anak-anak jalanan di sekitar Pinang Baris Kecamatan Sunggal:

1. Langkah pertama yang dilakukan Da'i adalah menjelaskan tentang hal-hal yang berkaitan dengan masalah-masalah agama yang patut menjadi perhatian anak-anak jalanan. Dengan artian menjelaskan dengan daya serap yang dimiliki oleh anak dalam menanamkan nilai-nilai agama Islam yang dianutnya. Diawali dengan menghafal rukun iman dan rukun islam, setelah itu dilanjutkan kepada hal-hal yang mendasar lainnya.

2. Kemudian para Da'i memberikan contoh tauladan, yaitu bagaimana seharusnya dilakukan, seperti mencontohkan tata cara melaksanakan shalat, membaca ayat-ayat Al-Qur'an dengan baik dan benar, mengajari anak tentang pola bicara yang santun, bagaimana cara memilih teman yang baik dan sebagainya.

3. Selanjutnya menyuruh anak-anak jalanan untuk mengikuti atau mempraktekkan apa yang telah dicontohkan orang tua sehingga anak terbiasa dengan aturan-aturan agama Islam dan dapat mempraktekkannya dalam kehidupan sehari-hari.

4. Langkah selanjutnya yang dilakukan oleh Da'i mengontrol anak-anak jalanan sehingga mereka tetap merasa diawasi oleh orang tua mereka dan Da'i sebagai pengarah gerak-gerik yang mereka lakukan. Pada gilirannya anak-anak jalanan tetap berprilaku sesuai dengan syariat Islam walaupun orang tuanya tidak berada di sekitarnya.

5. Da'i harus memiliki sikap toleransi terhadap anak-anak jalanan, maksudnya apabila anak-anak jalanan melakukan kesalahan hendaknya menasehatinya dengan bahasa yang lembut tanpa bermaksud memanjakannya agar anak-anak jalanan terbiasa memaafkan kesalahan dan berlaku santun terhadap orang lain.

6. Bagaimanapun marahnya, Da'i tidak boleh mengeluarkan kata-kata kasar dan umpatan di depan anak-anak jalanan tersebut agar anak-anak tidak menirunya. 
7. Menceritakan kisah-kisah Nabi dan para sahabat, agar menjadi teladan bagi anak-anak jalanan.

8. Mengenal nilai-nilai moral dan praktek seperti mencuci tangan sebelum makan, membaca Bismillah sebelum makan minum, membiasakan memasukkan makanan minuman dengan menggunakan tangan kanan, dan menganjurkan membaca doa sebelum tidur.

9. Memisahkan tempat tidur anatara anak laki-laki dan anak perempuan.

B. Hambatan Strategi Komunikasi Da'i Dalam Menanamkan Nilai-Nilai Agama Kepada Anak-Anak Jalanan Di Pinang Baris Kecamatan Medan Sunggal

Kegiatan penanaman nilai-nilai agama yang dilakukan Da'i di Pinang Baris Kecamatan Medan Sunggal menemui beberapa problema atau hambatan. Dari hasil wawancara dengan Ibu Wina pada tanggal 29 april pukul 09.30 WIB, terdapat hambatan dalam menanamkan Nilai-nilai agama. Hambatanhambatannya sebagai berikut:

\section{Anak-Anak Jalanan Sulit Diatur}

Menurut para Da'i anak sulit diatur atau suka melawan, kita jangan langsung menyalahkan mereka, sebab apapun yang menjadi keluhan orang tua tentang anaknya, sebenarnya adalah kesalahan orang tua itu sendiri, karena orang tualah yang mendidiknya dari dia kecil, dan karena orang tualah yang sering menasehati mereka dan kini Da'i ikut andil untuk bisa mempengaruhi mereka ke arah yang positif dengan menananmkan nilai-nilai agama kepada mereka.contohnya anak-anak jalanan yang sulit diatur, saat disuruh shalat ada yang tidak mau melaksanakan shalat. Ada yang menyebab anak-anak jalanan tersebut bersikap bandel, yaitu antara lain:

a. Kurang perhatian dan kasih sayang orang tua

Anak-anak jalanan membangkang karena ingin mendapatkan perhatian dari orang tuanya. Hal ini bisa saja terjadi salah satunya karena anak merasa jarang diperhatikan dan hanya bisa berkomunikasi ketika ada yang tidak benar pada anak.

b. Orang tua tidak kompak

Salah satu orang tua mereka memotivasi mereka agar bersekolah, misalnya seorang ibu. Namun si ayah menyuruh anaknya bekerja di jalanan sehingga masa depan anak menjadi tidak cerah. 
c. Campur tangan orang lain

Saat orang tua sudah kompak dalam mendidik putra-putrinya sering kali muncul kehadiran pihak lain, misalnya teman-teman nya mengajak tidak usah sekolah sehingga anak pun mudah terpengaruhi.

d. Menakut-nakuti anak-anak jalanan

Misalnya orang tua mereka menakuti anak-anaknya, tidak akan dikasih makan kalau tidak bekerja, sehingga mau tak mau tidak bersekolah demi kebutuhan keluarnganya.

Bila anak-anak menunjukkan sikap yang sulit diatur, Da'i mencoba mengatasinya dengan melakukan beberapa cara berikut:

a. Melibatkan anak-anak jalanan untuk membuat aturan bersama.

Ketika anak-anak jalanan melanggar, ia bisa diingatkan lagi mengenai aturan-aturan yang telah disepakatinya. Buat konsekuensi dari pelanggaran tersebut berupa hukuman yang juga disetujui oleh anak-anak jalanan. Jadi ketika mendapat hukuman, anak-anak jalanan tersebut tidak kaget lagi karena ia yang menyetujui konsekuensi tersebut. Dan contoh aturannya, berbicara dengan sopan kepada orang yang lebih tua.agar saling menghargai. Apabila melanggar, anak tersebut akan diberikan hukuman sesuai dengan yang telah ditetapkan bersama.

b. Bangun mental juang anak-anak.

Biasakan agar anak mendapatkan sesuatu dengan perjuangan misalnya ia akan mendapatkan mainan apabila dapat membuat prestasi tertentu. Biasakanlah memberinya sesuai kebutuhan anak-anak jalanan. Jika anak jalanan menginginkan lebih, anak harus melakukan sesuatu yang bermanfaat atau membanggakan agar bisa mendapatkan uang lebih tersebut. Contoh perkataan Bapak Irwan yang merupakan salah seorang Pembina anak-anak jalanan sebagai berikut: Nak.. jika kamu ingin mendapatkan hadiah, maka kamu harus berusaha dan berdo'a.

c. Bangun kepercayaan diri mereka.

Biasakan untuk memuji setiap perbuatan baik yang dilakukan anak-anak jalanan di rumah singgah tersebut sekecil apapun, untuk membangun kepercayaan dirinya. Berikan sebutan-sebutan yang membuat anak-anak 
jalanan bangga kepada dirinya seperti "si pintar" atau "si cantik" atau "si cerdas". Contoh perbuatannya yaitu menolong orang lain yang membutuhkan pertolongan seperti mendorong kereta orang di jalan. Maka berikanlah pujian padanya dengan mengatakan kamu anak yang baik. Dan contoh lain seperti, anak-anak jalanan tersebut pandai membaca huruf hijaiyah, yang merupakan dasar untuk bisa membaca Al-Qur'an.

d. Bangun museum kasih Ibu.

Abadikan setiap momen bersama anak-anak jalanan, misalkan foto ketika berjalan-jalan bersama ke sesuatu tempat, foto ketika bermain bola, menyimpan video tari-tarian dan bermain musik bersama. Semua benda kenangan tersebut dapat dibuka dan dikenang bersama anak-anak jalanan suatu hari, untuk mengingatkan anak-anak jalanan akan masa-masa bahagia bersama pembina atau para Da'i dan bersama sahabat-sahabatnya.

\section{Kurangnya Pengawasan (Kontrol) Ketika Anak-Anak Jalanan Berada Di Jalanan}

Menurut Ibu Wina pada wawancara tanggal 29 April 2011 pukul 09.30 WIB di rumah singgah PKPA, beliau menyatakan kurangnya pengawasan mereka saat mereka berada di jalanan ketika melakukan kegiatan mereka masing-masing disebabkan karena para Da'i juga punya jadwal atau kerja mereka di luar. Namun Da'i berupaya untuk bisa membagi waktunya dengan anak-anak jalanan agar dapat nantinya terjun ke dunia lapangan bersama anak-anak jalanan di jalanan. Agar anak-anak jalanan selalu menampilkan dirinya dengan nilai-nilai agama Islam, yang bersifat positif kapan dan dimanapun. Dalam hal ini sekaligus untuk membuktikan bahwa pengetahuan, pemahaman dan pengamalan ajaran agama yang dimiliki Da'i berkontribusi positif terhadap penanaman nilai-nilai beragama anak-anak jalanan.

\section{Lingkungan Yang Tidak Kondusif}

Menurut Bapak Irwan Hadi pada wawancara tanggal 28 April 2011 di rumah singgah PKPA pada pukul 08.30 WIB bahwa wilayah pemukiman penduduk Pinang Baris Kelurahan Lalang Kecamatan Medan Sunggal terkesan kurang nyaman. Lingkungan pergaulan anak-anak yang mengadopsi budaya kota sudah semakin nyata. Gaya hidup materialistis yang begitu tinggi, penampilan 
untuk saling menonjolkan diri turut mewarnai kehidupan anak-anak. Contohnya: memakai anting-anting. Inipun sesuai dengan pengamatan penulis bahwa banyak anak-anak jalanan memakai asesoris dijalanan. Menurut Da'i kehidupan beragama di kalangan anak-anak semakin tertinggal. Para Da'i beranggapan kalau hal ini juga menjadi hambatan bagi mereka, namun mereka akan tetap terus menanamkan nilai-nilai agama kepada anak-anak jalanan agar tidak terpengaruhi dengan lingkungan yang kurang baik. Selain itu Pak Irwan juga menjelaskan keberadaan lingkungan yang demikian ini berdampak terhadap pembentukan buruknya sikap mental anak, termasuk mental beragamanya. Lingkungan tidak mencerminkan kehidupan yang religius, tidak akan dapat membantu pembentukan dan penanaman nilai-nilai keberagamaan anak-anak yang tumbuh dan berkembang di dalamnya.

\section{SIMPULAN}

Berdasarkan hasil penelitian di atas, maka penelitian ini dapat disimpulkan sebagai berikut:

1. Strategi komunikasi Da'i dalam menanamkan nilai-nilai agama kepada anak-anak jalanan di Pinang Baris Kecamatan Medan Sunggal terdapat beberapa bentuk. Pertama Da'i memberikan pengarahan sepenuhnya dan berupaya memberikan motivasi kepada mereka agar mau bersekolah. Kedua Da'i menunjukkan ketauladanan dalam kehidupan sehari-hari. Perilaku Da'i yang didasarkan pada pokokpokok ajaran agama terlebih dahulu dikerjakan Da'i dan selanjutnya Da'i secara berangsur-angsur mengajarkan kepada anak-anak jalanan. Ketiga Da'i mengajarkan anak-anak jalanan melaksanakan shalat, membaca Al-Qur'an dengan memberikan pengarahan agar dapat diamalkan mereka dalam kehidupannya.

2. Hambatan-hambatan yang dirasakan Da'i dari anak-anak jalanan di Pinang Baris Kecamatan Medan Sunggal dalam menanamkan nilainilai agama kepada anak-anak jalanan mencakup persoalan anak-anak jalanan yang sulit diatur (bandel), kurangnya pengawasan (kontrol) ketika mereka berada di jalanan dan faktor lingkungan yang tidak kondusif.

\section{DAFTAR PUSTAKA}

Aidil. 2010. Srategi Komunikasi Orang Tua Kepada Anak. Medan: Fakultas Dakwah IAIN Sumatera Utara 
Arifin, H. M 1984. Hubungan Timbal Balik Pendidikan Agama di Lingkungan Sekolah dan Keluarga. Jakarta: Bulan Bintang

Effendy, U. Onong. 1981. Dimensi-Dimensi Komunikasi. Bandung: Remaja Rosda Karya

Rosda Karya

1989. Dimensi-Dimensi Komunikasi. Bandung: Remaja

1990. Dimensi-Dimensi Komunikasi. Bandung: Remaja

Rosda Karya

2004. Dimensi-Dimensi Komunikasi. Bandung: Remaja

Rosda Karya

Kasiran, Moh. 1993. Ilmu Jiwa Perkembangan. Surabaya: Usaha Nasional

Ritzer, George, dan Douglas J. Godman. 2004 Teori Sociology Modern. Diterjemahkan oleh Tribuwono B. S. Jakarta: Kencana

Sajogyo, Pudjiwati. 1985. Sosiologi Pembangunan. Jakarta: Fakultas Pasca Sarjana IKIP Jakarta bekerja sama dengan Badan Koordinasi Keluarga Berencana Nasional

Sukanto, Soejono. 1991. Beberapa Permasalahan di Jalan Raya. Dalam Masyarakat Dan Kebudayaan: Kumpulan Karangan Untuk Prof. Dr. Selo Soemardjan. Jakarta: Djambatan 